\title{
Penyediaan Air Bersih Berbasis Masyarakat Sebagai aktualisasi SDG's di Kabupaten Madiun
}

\author{
Ronnawan Juniatmoko ${ }^{1}$, Susanti Erikania ${ }^{2}$ \\ ${ }^{1}$ Program Studi Sains dan Teknologi IAIN Surakarta \\ ${ }^{2}$ STIKES Bhakti Husada Mulia Madiun \\ Surel: ${ }^{1}$ rjuniatmoko9@gmail.com, ${ }^{1}$ ronnawan.juniatmoko@iain-surakarta.ac.id, \\ newerikania@gmail.com
}

\section{ABSTRAK}

SDG's merupakan kelanjutan dari $M D G$ 's. Dari hasil evaluasi diperlukan langkah konkret untuk mewujudkan pembangunan global pada tahun 2016-2030. Salah satu tujuan $S D G$ 's pada pilar pembangunan lingkungan hidup antara lain memastikan ketahanan pangan dan gizi yang baik, mencapai akses universal ke air dan sanitasi. Akses universal air menjadi prioritas pemerintah, melalui gerakan 100-0-100 yaitu mentargekan penyediaan $100 \%$ akses aman air minum, 0\% kawasan permukiman kumuh, dan $100 \%$ akses sanitasi layak. Kebutuhan akan air oleh manusia tidak ada habisnya, terutama air bersih. Maka dalam rangka percepatan capaian akses air bersih di wilayah Indonesia, perlu adanya evaluasi dari aspek teknologi, sosial, dan budaya. Pada studi kasus program percepatan capaian air bersih, Kabupaten Madiun, Desa Bodag menjadi salah satu kawasan strategis yang memiliki potensi sumber daya alam sebagai wilayah konservasi lingkungan dalam pelestarian hutan dan perlindungan air bersih. Sehingga memiliki potensi sumber mata air yang berkualitas. Namun permasalahan yang yang terjadi, hampir seluruh masyarakat tidak memiliki akses air bersih yang layak. Sehingga, penerapan teknologi distribusi air bersih diaplikasikan untuk meningkatkan kapasitas penduduk yang terlayani dengan air bersih dan diharapkan dapat mempercepat capaian akses aman air minum Indonesia di tahun 2020.
\end{abstract}

\section{Kata kunci}

Air Bersih, $S D G$ 's, Kabupaten Madiun

\section{PENDAHULUAN}

Permasalahan lingkungan tidak terlepas dengan adanya permasalahan air bersih dan sanitasi yang berhubungan dengan keberlangsungan tingkat kesehatan masyarakat. Permasalahan ini sudah menjadi permasalahan global, hingga timbulnya Tujuan SDG's (Sustainable Development Goals) pada pilar pembangunan lingkungan hidup yang disepakati pada 25 September 2015. Komitmen International ini juga dijadikan salah satu acuan bagi Indonesia sebagai komitmen untuk mengembangkan penyediaan $100 \%$ akses aman air minum. Perencanaan $100 \%$ akses aman air minum melibatkan partisipasi masyarakat ini menjadi penekanan pada $S D G$ ' ${ }^{[1]}$.

Salah satu masalah pokok yang dihadapi adalah berkurangnya tersedianya akses sumber air yang bersih adalah karena adanya pencemaran oleh limbah industri dan limbah domestik, sehingga beban dalam segi 
pengelolaan air bersihnya semakin meningkat ${ }^{[2]}$.

Selain itu belum meratanya pelayanan penyediaan air bersih, terutama pada daerah perdesaan. Sumber air bersih yang tersedia belum dapat dimanfaatkan secara maksimal. Maka dalam rangka penyediaan kebutuhan air bersih yang memenuhi syarat kesehatan, pemerintah RI mencanangkan programprogram peningkatan penyediaan air bersih dan pemanfaatan sumber air yang ada secara optimal $^{[3]}$.

Kabupaten Madiun merupakan salah satu kabupaten yang dikelilingi oleh beberapa pegunungan yaitu Gunung Lawu pada sebelah Barat, Gunung Pandan pada sebelah utara, Gunung Wilis pada sebelah selatan dan gugusan Gunung Kelud pada sebelah Timur. Desa Bodag, Kecamatan Kare terletak pada pegunungan Wilis yang mana sebagai wilayah konservasi lingkungan dalam pelestarian hutan dan perlindungan air bersih.

Desa Bodag memiliki potensi sumber mata air yang berkualitas. Namun, masyarakat di sekitar Desa Bodag masih banyak yang tidak mendapatkan akses air bersih yang memadai karena kurang adanya akses air bersih. Selain itu penyediaan air bersih tidak merata dikarenakan air bersih yang layak untuk memenuhi kebutuhan rumah tangga sehari-hari dimanfaatkan juga untuk menyiram perkebunan cengkeh, kakao dan kopi. Dalam studi ini, akan dibahas mengenai kondisi daerah studi (Kabupaten Madiun) dengan aspek sosial dan ekonomi yang melatarbelakangi keterbatasan akses air bersih tersebut.

Mengingat peran air bersih yang sangat penting bagi kelangsungan hidup manusia maka perlu upaya perencanaan sistem penyediaan air bersih dengan sumber air baku berasal dari Sumber mata air Gunung Wilis dan di manfaatkan untuk memenuhi kebutuhan air bersih masyarakat di desa Bodag.

\section{METODE PENELITIAN}

Penelitian dilakukan selama 3 minggu. Meliputi wawancara langsung dan penyebaran kuisioner di beberapa rumah tangga, Polindes, Puskesmas Kecamatan Kare, Dinas Kesehatan
Kabupaten Madiun, hingga Dinas Perumahan dan Kawasan Permukiman Kabupaten Madiun untuk mengetahui keadaan sebenarnya di lapangan. Ruang lingkup kuisioner rumah tangga dibagikan bagi penduduk yang sudah mendapatkan program air bersih yang akan dianalisa dampak perubahan perilaku terhadap kebutuhan air bersih.

Pengamatan kondisi eksisting dengan kajian sosial masyarakat kemudian dilanjutkan dengan analisis pengumpulan data. Evaluasi dilakukan dengan menganalisis penyediaan air bersih, pemanfaatan mata air, dan lembaga pemerintahan/komunitas masyarakat yang turut serta dalam pengelolaan air bersih. Kemudian dilakukan perecanaan teknologi dalam penyediaan air bersih yang diperkuat dengan studi pustaka ${ }^{[4]}$.

\section{HASIL DAN PEMBAHASAN}

Hasil dan pembahasan berdasarkan survei dan analisis kondisi eksisting dan perencanaan menngunakan software epanet dan autocad.

\section{Analisis Kondisi Eksisting Fasilitas Air Bersih}

Menurut survei yang telah dilakukan pada tanggal 3-12 Februari 2020, didapatkan bahwa tingkat pendidikan di Desa Bodag sebanyak $48 \%$ merupakan lulusan SD. Sedangkan lulusan SMP dan SMA berturutturut sebanyak $28 \%$ dan $20 \%$ serta $4 \%$ lulusan Perguruan Tinggi. Jenis pekerjaan penduduk Desa Bodag adalah sebagian besar adalah petani dan peternak, yaitu sebanyak $89 \%$ dan $11 \%$. Hal ini membuktikan bahwa seluruh penduduk merupakan petani. Dari hasil survei yang telah dilakukan, didapatkan hasil bahwa pendapatan bersih penduduk Desa Bodag adalah sebanyak Rp. 700.000,sebesar 66\%, lalu Rp. 500.000 sebesar 15\%, dan Rp. 1.200.000 sebesar 19\%. Pendapatan ini merupakan pendapatan untuk satu rumah dengan total per bulan yang sudah dikurangi untuk pengeluaran pembelian pupuk untuk pertanian dan perkebunan.

Kondisi ketersediaan air bersih di Desa Bodag sebenarnya tidak terlalu memprihatinkan. Dikenal dengan salah satu 
kawasan hutan lindung Gunung Wilis, Desa Bodag menjadi salah satu kawasan dengan mata air yang berlimpah sekaligus dengan kualitas air bersih yang tergolong baik. Berikut merupakan salah satu mata air yang dimanfaatkan oleh masyarakat sekitar.

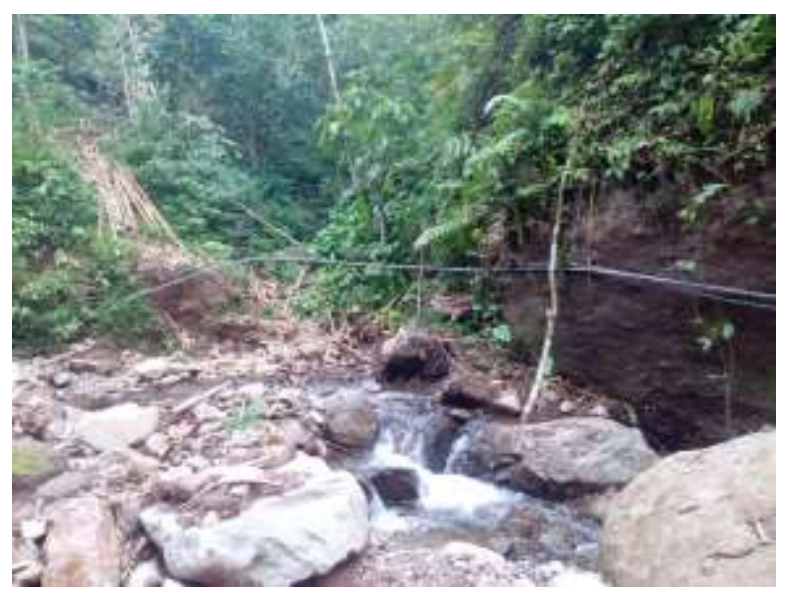

Gambar 1. Salah satu mata air yang digunakan warga Desa Bodag

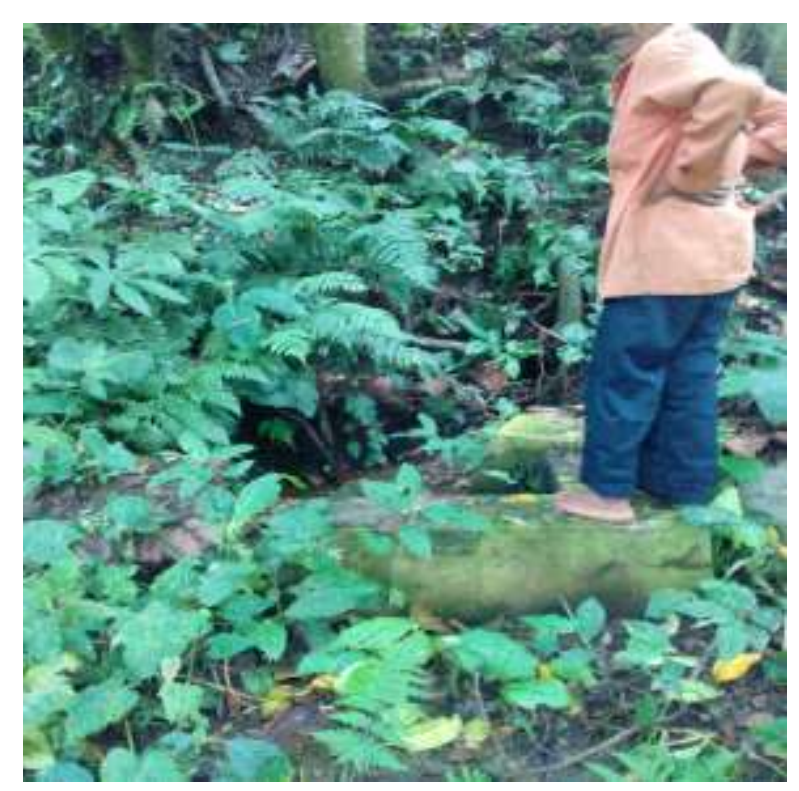

Gambar 2. Penangkap Mata Air

Salah satu permasalahan yang ada di Desa Bodag adalah sumber mata air yang jauh dari wilayah penduduk, dan tidak adanya sistem distribusi perpipaan yang baik untuk mengalirkan mata air tersebut. Sehingga hanya sebagian kecil masyarakat memanfaatkan mata air rembesan terdekat. Mata air (rembesan) tersebut memiliki debit yang kecil sehingga hanya dapat dimanfaatkan oleh sekelompok penduduk disekitar mata air. Beberapa penduduk memasang pipa distribusi yang sangat sederhana ataupun harus membawa air dengan timba. Sedangkan penduduk yang tinggal jauh dari jangkauan mata air, harus berjalan beberapa kilometer untuk mendapat air bersih. Selain itu masyarakat terdekat dengan rembesan air tersebut menggunakan air bersih untuk menyiram perkebunan masyarakat.

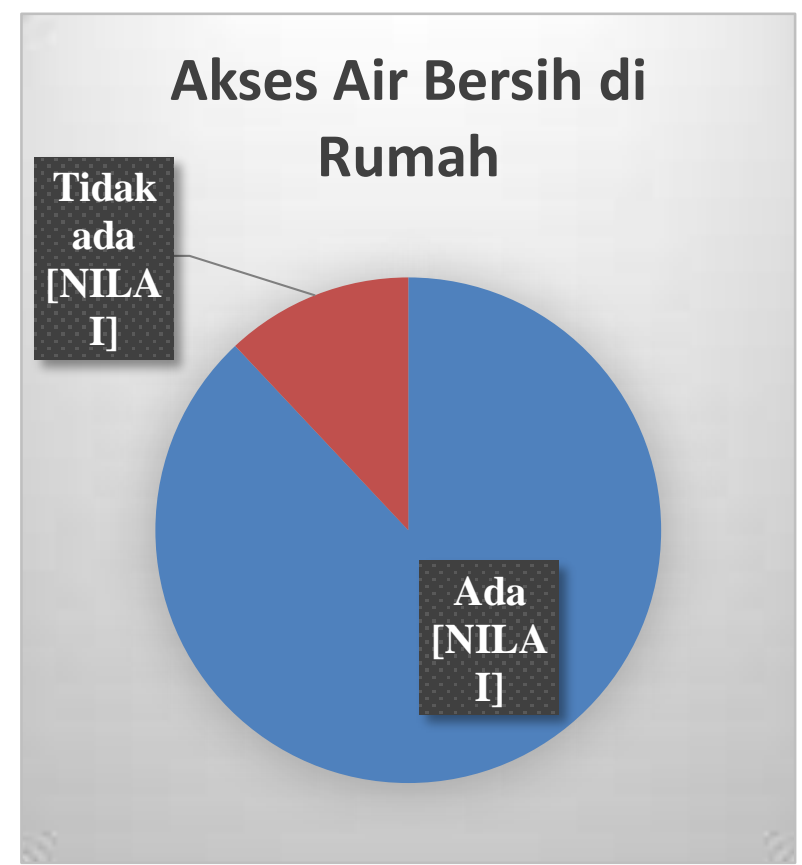

Gambar 3. Ketersediaan akses Bersih Sumber: hasil survey

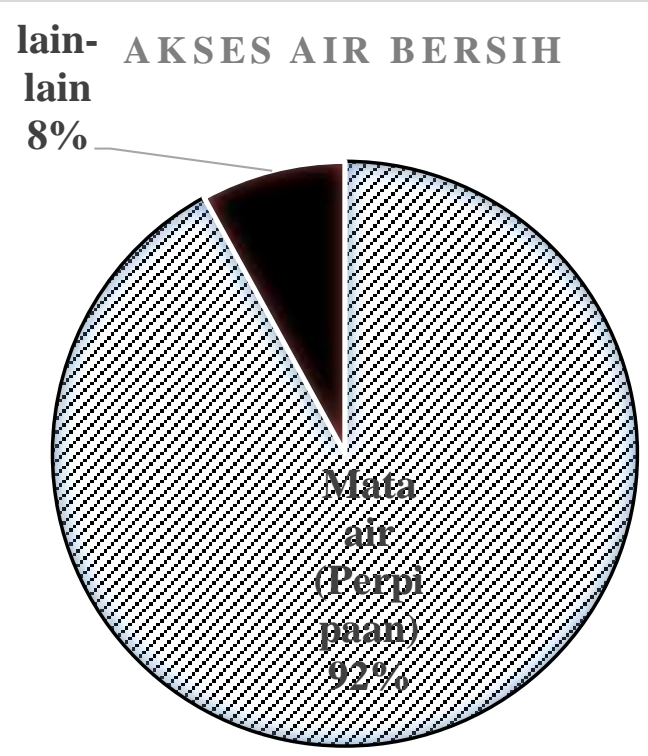

Gambar 4. Akses Air Bersih 
Gambar 3 menyatakan penduduk Desa Bodag yang sudah memiliki akses air bersih di rumah adalah $88 \%$. Dari hasil data survei dapat dilihat bahwa, sebagian besar penduduk tersebut sudah memiliki akses air bersih. Hal ini dikarenakan oleh adanya kebutuhan operasional perkebunan dan pertanian.

Gambar 4 menyatakan diantara penduduk yang sudah mendapat akses air bersih ternyata sebesar $8 \%$ responden yang jauh dari mata air dan sistem perpipaan, mengakses air bersih dengan menggunakan air sumur gali, air permukaan sungai dan air sumur dangkal. Sedangkan 92\% mendapat air bersih dari mata air (perpipaan). Hal ini menunjukkan akses air bersih menjadi suatu kebutuhan pokok dalam perkebunan dan lahan pertanian masyarakat. Kasus di Desa Bodag menunjukkan lahan perkebunan cengkeh dan pertanian yang sudah dijalankan telah meningkatkan kebutuhan air bersih, sedangkan lahan perkebunan dan pertanian masyarakat dapat menggunakan air permukaan sungai yang kualitas air tidak sama dengan kualitas air layak minum.

Permasalahan air bersih lainnya adalah adanya sistem perpipaan mandiri penduduk yang tidak sesuai dengan kriteria ditribusi perpipaan air minum. Masyarakat secara langsung mengambil air dari sumber mata air dengan teknik perpipaan yang sangat sederhana dan tidak terencana dengan baik. Kebocoran pipa banyak terjadi, baik di sambungan antar pipa maupun retakanretakan pipa akibat tertindih beban berat (akibat tidak tertanam di dalam tanah) ${ }^{[5]}$.

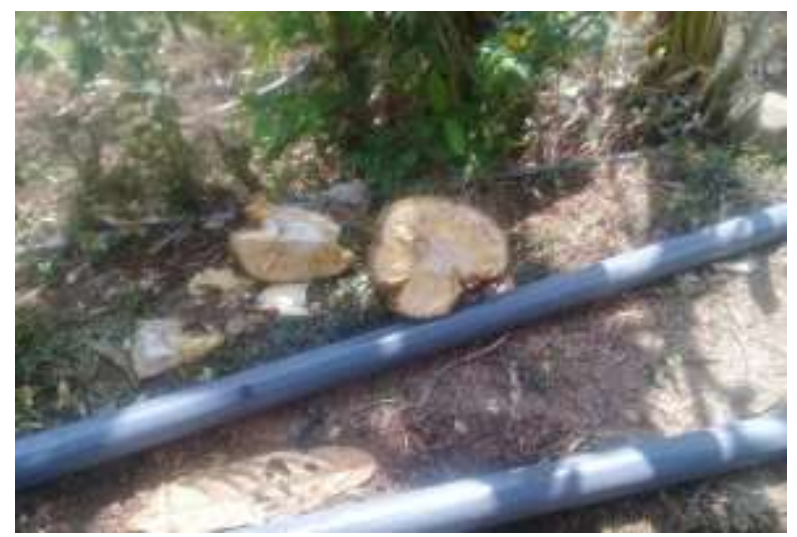

Gambar 5. Perpipaan PVC yang tidak tertanam dalam tanah

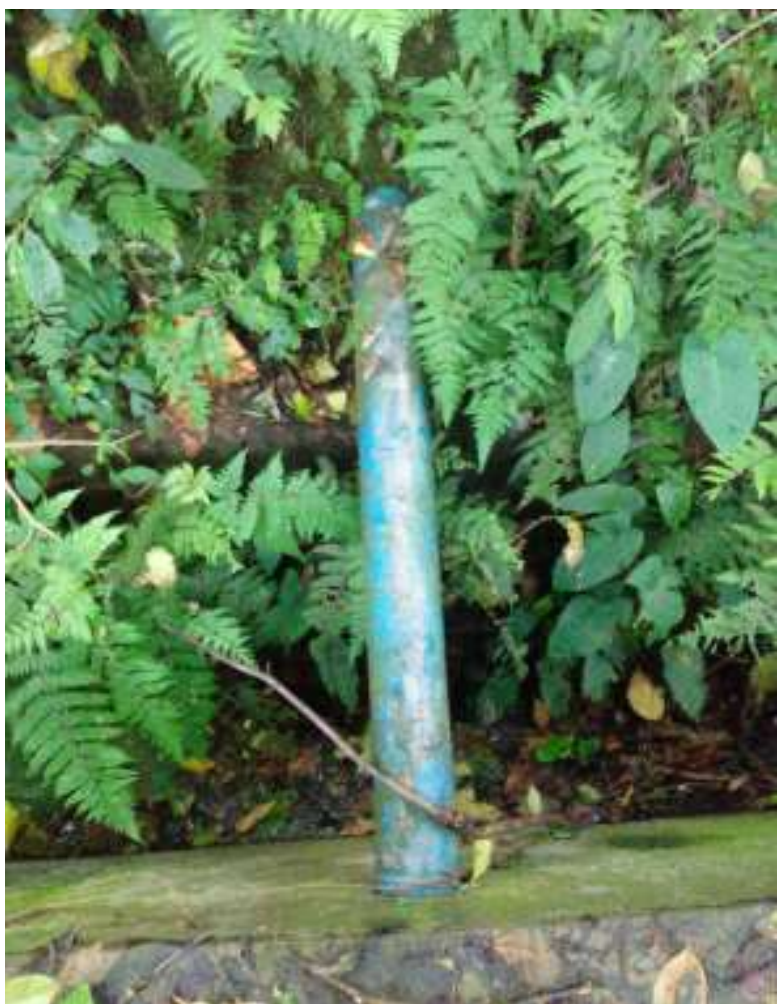

Gambar 6. Kebocoran Pipa

\section{Perencanaan Sistem Air Bersih}

Pada sistem distribusi masyarakat Desa Bodag ini akan direncanakan dengan fasilitas sambungan halaman. Untuk pipa yang akan dipasang sampai ke dalam rumah dibebankan ke masing-masing pemilik rumah sesuai dengan keinginan mereka yang beragam. Berdasarkan Desa Bodag (2019) sebanyak 1655 jiwa. Dengan proyeksi 10 tahun, diperkirakan jumlah penduduk meningkat sebanyak 20\%. Sehingga jumlah penduduk yang terlayani $=100 \% \times 1.2=1986$ jiwa $^{[6]}$.

Untuk perhitungan pembagian SR diasumsikan kebutuhan air 100L/jiwa/hari. Sehingga jumah sambungan rumah didapatkan 397 rumah dengan $\mathrm{Q}_{\text {domestik }}=2,54$ L/detik. Kebutuhan non domestik ditentukan dari fasilitas yang dimiliki oleh daerah tersebut seperti sekolah, tempat ibadah, fasilitas tempat kesehatan, dan industri $(2,54$ L/detik).

Sehingga kebutuhan air total (2,77 L/detik) dihitung dengan menjumlahkan kebutuhan air pada jam puncak dengan kebutuhan air untuk pemadam kebakaran (20\% dari debit total). Sehingga kebutuhan air total+kebocoran $=3,33 \mathrm{~L} /$ detik. Untuk menghitung besarnya $\mathrm{Q}_{\mathrm{hm}}$ (Debit harian 
maksimum) digunakan faktor harian maksimum (f) sebesar 1,2. Angka ini diperoleh dari analisa data kapasitas produksi dan kapasitas distribusi oleh mata air ${ }^{[7]}$.

Sebaiknya untuk menentukan faktor harian maksimum dilakukan penelitian khusus mengenai pola pemakaian air per hari. Dengan adanya pola pemakaian tersebut akan di dapat titik tertinggi pemakaian air per hari. Titik tersebut yang akan dijadikan faktor harian maksimum didapatkan dari fluktuasi pemakaian air dari KPSPAMS sehingga didapatkan $\mathrm{Q}_{\mathrm{hm}}=3,99$ L/detik.

Untuk menghitung besarnya $\mathrm{Q}_{\mathrm{jm}}$ (Debit jam maksimum) digunakan faktor jam maksimum $\left(f_{j m}\right)$. Faktor jam maksimum ditentukan oleh kebiasaan dan pola aktivitas dari populasi yang menempati. Fluktuasi kebutuhan air timbul karena kegiatan masyarakat dalam penggunaan air yang berbeda pada tiap jam, hari, minggu, atau bulan. Dari keseluruhan aktivitas sehari tersebut dapat diketahui kondisi konsumsi rata-rata pada hari tersebut. Diasumsikan fluktuasi kebutuhan air jam puncak dalam sehari, sehingga diambil nilai 2 sehingga didapatkan $\mathrm{Q}_{\mathrm{jm}}=6,66 \mathrm{~L} /$ detik. Jadi kebutuhan total dalam Desa Bodag adalah sebesar 6.66 L/detik. Gambar 7 merupakan rencana sistem penyediaan air bersih berdasarkan survei sebaran penduduk.

Ada tiga sumber mata air yang terdapat di Desa Bodag, akan tetapi sumber air bersih yang digunakan oleh masyarakat Desa Bodag adalah berasal dari mata air Sumber Nanas yang memiliki debit 8 liter/detik. Perencanaan kali ini menggunakan bangunan penangkap mata air (PMA) (broncaptering) untuk pemeliharaan kuantitas dan kualitas sumber mata air. Diasumsikan waktu detensi air pada
PMA sebesar 60 detik, sehingga volume yang akan ditampung $=\mathrm{Q} \times \mathrm{td}=0.48 \mathrm{~m}^{3}$. Kemudian diasumsikan dimensi bak panjang $(\mathrm{p})=$ lebar (1), sehingga didapatkan tbak (tinggi bak) = $0,48 \mathrm{~m}^{[8]}$. Jadi dimensi bangunan penangkap mata air tersebut adalah $1 \mathrm{~m} \times 1 \mathrm{~m} \times 0.5 \mathrm{~m}$ (pxlxt).

Mata air Sumber Nanas ini tidak hanya dimanfaatkan untuk memenuhi kebutuhan air bersih masyarakat namun digunakan untuk mengairi irigasi ladang dan perkebunan cengkah masyarakat Desa Bodag. Oleh karena itu pada bangunan penangkap mata air ini akan dibuat 3 pipa overflow dengan kebutuhan air yang bervariasi: (a) Digunakan kebutuhan air harian rata-rata $\left(\mathrm{Q}_{\mathrm{rh}}=3.33\right.$ liter/detik), dengan waktu detensi 60 detik dan dimensi $\mathrm{P}=\mathrm{L}$ sehingga ketinggian pipa overflow $\mathrm{t}=0.2 \mathrm{~m}$; (b) Digunakan kebutuhan air harian maksimum $\left(\mathrm{Q}_{\mathrm{hm}}=3.99\right.$ liter/detik $)$, sehingga ketinggian pipa overflow $\mathrm{t}=0.24 \mathrm{~m}$; (c) Digunakan kebutuhan air jam maksimum $\left(\mathrm{Q}_{\mathrm{jm}}=6.66\right.$ liter/detik), sehingga ketinggian pipa overflow $\mathrm{t}=0.4 \mathrm{~m}$. Gambar 7 menunjukkan peta rencana sistem penyediaan air bersih Desa Bodag.

Analisis perencanaan sistem distribusi air bersih menggunakan software EPANET. Seluruh data elevasi, titik junction (node), debit, panjang pipa dan diameter pipa dimasukkan ke dalam software. Data diameter yang digunakan adalah diameter dalam dan yang sesuai dipasaran. Dalam tugas perencanaan ini digunakan pipa PVC dengan kriteria SNI S12,5 dengan arti kekuatan pipa tersebut adalah 10 bar $^{[9]}$.

Tabel 1 berikut adalah tabel hasil perhitungan pressure dan head yang dihasilkan dari perencanaan istem distribusi Desa Bodag.

Tabel 1. Network Node Epanet

\begin{tabular}{cccccc}
\hline \multicolumn{5}{c}{ Network Table - Nodes } \\
\hline \multirow{2}{*}{ Node ID } & \multirow{2}{*}{ Elevation (m) } & $\begin{array}{c}\text { Base } \\
\text { Demand (LPS) }\end{array}$ & Demand (LPS) & Head (m) & Pressure (m) \\
\hline Junc P1 & 666 & 0 & 0 & 708.39 & 42.39 \\
Junc RT27 & 666 & 0.15 & 0.18 & 708.84 & 42.84 \\
Junc RT32 & 670 & 0.18 & 0.22 & 709.12 & 39.12 \\
Junc RT33 & 675 & 0.15 & 0.18 & 709.45 & 34.45 \\
Junc RT24 & 790 & 0.18 & 0.22 & 827.55 & 37.55 \\
Junc RT25 & 750 & 0.14 & 0.17 & 759.9 & 9.9
\end{tabular}


Tabel 1. (lanjutan) ...

\begin{tabular}{cccccc}
\hline \multicolumn{5}{c}{ Network Table - Nodes } \\
\hline Node ID & Elevation (m) & $\begin{array}{c}\text { Base } \\
\text { Demand (LPS) }\end{array}$ & Demand (LPS) & Head (m) & Pressure (m) \\
\hline Junc RT26 & 700 & 0.18 & 0.22 & 755.36 & 55.36 \\
Junc RT2930 & 690 & 0.48 & 0.58 & 702.12 & 12.12 \\
Junc RT34 & 660 & 0.25 & 0.3 & 707.72 & 47.72 \\
Junc RT20 & 670 & 0.28 & 0.34 & 703.96 & 33.96 \\
Junc RT21 & 680 & 0.16 & 0.19 & 703.33 & 23.33 \\
Junc RT22 & 680 & 0.21 & 0.25 & 703.98 & 23.98 \\
Junc RT23 & 670 & 0.1 & 0.12 & 705.02 & 35.02 \\
Junc RT31 & 650 & 0.36 & 0.43 & 706.3 & 56.3 \\
Junc RT28 & 700 & 0.26 & 0.31 & 709.37 & 9.37 \\
Junc P2 & 666 & 0 & 0 & 707.64 & 41.64 \\
Junc P3 & 666 & 0 & 0 & 705.39 & 39.39 \\
Junc P4 & 700 & 2.58 & 3.1 & 751.27 & 51.27 \\
Junc 4 & 830 & 3.08 & 3.7 & 893 & 63 \\
Junc 7 & 760 & 2.9 & 3.48 & 825.99 & 65.99 \\
Resvr 1 & 830 & \#N/A & -3.7 & 830 & 0 \\
Resvr 2 & 710 & \#N/A & -3.1 & 710 & 0 \\
Resvr 3 & 900 & \#N/A & -3.7 & 900 & 0 \\
Resvr 4 & 760 & \#N/A & -3.48 & 760 & 0 \\
\hline
\end{tabular}

Tabel 2 berikut ini adalah tabel diameter yang digunakan untuk sistem distribusi Desa Bodag.

Tabel 2. Network Link Epanet Running Success

\begin{tabular}{ccccccc}
\hline \multicolumn{7}{c}{ Network Table - Links } \\
\hline Link ID & Length $(\mathrm{m})$ & $\begin{array}{c}\text { Diameter } \\
(\mathrm{mm})\end{array}$ & Roughness & $\begin{array}{c}\text { Flow } \\
(\text { LPS })\end{array}$ & Velocity $(\mathrm{m} / \mathrm{s})$ & $\begin{array}{c}\text { Unit Headloss } \\
(\mathrm{m} / \mathrm{km})\end{array}$ \\
\hline Pipe 1 & 700 & 100 & 120 & 3.7 & 0.47 & 3.5 \\
Pipe 2 & 500 & 100 & 120 & 3.48 & 0.44 & 3.13 \\
Pipe 5 & 100 & 75 & 120 & 2.21 & 0.5 & 5.47 \\
Pipe 8 & 50 & 50 & 120 & 0.85 & 0.43 & 6.75 \\
Pipe 14 & 200 & 30 & 120 & 0.58 & 0.81 & 39.41 \\
Pipe 15 & 50 & 50 & 120 & 1.18 & 0.6 & 12.29 \\
Pipe 16 & 50 & 50 & 120 & 1 & 0.51 & 9.03 \\
Pipe 19 & 100 & 38 & 120 & 0.53 & 0.47 & 10.61 \\
Pipe 20 & 50 & 25 & 120 & 0.19 & 0.39 & 12.52 \\
Pipe 21 & 50 & 25 & 120 & 0.25 & 0.51 & 20.72 \\
Pipe 22 & 50 & 25 & 120 & 0.43 & 0.88 & 56.23 \\
Pipe 23 & 50 & 30 & 120 & 0.31 & 0.44 & 12.66 \\
Pipe 24 & 100 & 25 & 120 & 0.2 & 0.41 & 13.95 \\
Pipe 25 & 50 & 19 & 120 & -0.1 & 0.34 & 13.33 \\
Pipe 26 & 100 & 50 & 120 & 0.9 & 0.46 & 7.48 \\
Pipe 27 & 300 & 50 & 120 & 0.9 & 0.46 & 7.48 \\
Pipe 28 & 50 & 50 & 120 & 0.9 & 0.46 & 7.48 \\
Pipe 4 & 2000 & 100 & 120 & 3.7 & 0.47 & 3.5 \\
Pipe 7 & 10 & 25 & 120 & 0.17 & 0.34 & 9.78 \\
Pipe 9 & 400 & 75 & 120 & 3.31 & 0.75 & 11.59 \\
Pipe 10 & 400 & 75 & 120 & 3.1 & 0.7 & 10.23 \\
\hline
\end{tabular}


Pada perencanaan sistem distribusi air bersih ini direncanakan satu buah bangunan penangkap air minum, 1 buah bak pelepas tekan dan 2 buah reservoar. Dibutuhkan satu buah bak Pelepas tekan yang akan diletakkan diantara bangunan penangkap mata air dan reservoar 1 dikarenakan beda tinggi yang amat besar antara kedua bangunan tersebut. Dengan data perencanaan sebagai berikut: $\mathrm{L}$ $=2700 \mathrm{~m} ; \mathrm{DH}=110 \mathrm{~m} ; \mathrm{Q}_{\mathrm{rh}}=3.33$ liter $/$ detik; $\mathrm{C}=120$, menggunakan rumus Hazen Williams:

$\mathrm{Hf}=\frac{\mathrm{Lx} \mathrm{Q}^{1.85}}{\left(0.00155 \times \mathrm{x} \mathrm{d} \mathrm{d}^{2.63}\right)}{ }^{1.85}$

Keterangan :

$\mathrm{L}=$ panjang pipa $(\mathrm{m})$

$\mathrm{Q}=$ debit pipa $\left(\mathrm{m}^{3} /\right.$ detik $)$

$\mathrm{C}=$ koefisien kekasaran pipa $\left(0.00155^{*} c^{*} d\right)$

$\mathrm{D}=$ diameter pipa $(\mathrm{m})$

Jika digunakan $\mathrm{d}=10 \mathrm{~cm}$, maka $\mathrm{Hf}=7.64 \mathrm{~m}$ dan sisa head yang terjadi $=110 \mathrm{~m}-7.64 \mathrm{~m}=102.36$ m.

Dari perencanaan di atas didapatkan sisa head $102.36 \mathrm{~m}$. Pada perencanaan sistem distribusi air bersih masyarakat Desa Bodag ini digunakan pipa PVC SNI S 12,5 yang berarti pipa tersebut mampu menahan tekanan maksimum $80 \mathrm{~m}$. Jika sisa head $102.36 \mathrm{~m}$ dibiarkan terjadi di dalam pipa tersebut, maka pipa akan pecah. Untuk menghindari hal tersebut, maka direncanakan bak pelepas tekan (BPT) yang diletakan sebelum reservoar 1 atau pada beda tinggi maksimum $80 \mathrm{~m}$ dari bangunan penangkap mata air. Data perencanaan sebagai berikut: L $=2000 \mathrm{~m} ; \mathrm{DH}=70 \mathrm{~m} ; \mathrm{Q}_{\mathrm{rh}}=3.33$ liter/detik; $\mathrm{C}=120$. Jika digunakan $\mathrm{d}=10 \mathrm{~cm}$, maka, $\mathrm{Hf}$ $=5.66 \mathrm{~m}$. Sisa head yang terjadi $=70 \mathrm{~m}-5.66$ $\mathrm{m}=64.34 \mathrm{~m}$.
Bila menggunakan debit jam puncak $\left(\mathrm{Q}_{\mathrm{jm}}=\right.$ 6.66 liter/detik); $d=10 \mathrm{~cm}$ maka, $\mathrm{Hf}=20.41$ $\mathrm{m}$. Sisa head yang terjadi $=70 \mathrm{~m}-20.41 \mathrm{~m}=$ $49.59 \mathrm{~m}$.

Dari hasil perhitungan sisa head yang terjadi pada bak pelepas tekan di atas, dapat dilihat bahwa sisa head maksimum yang terjadi adalah $64.34 \mathrm{~m}$ dan sisa head minimum adalah $49.59 \mathrm{~m}$. Angka ini cukup aman untuk ditahan oleh pipa dan juga untuk distribusinya.

\section{Bill of Quantity (BOQ)}

Menurut kondisi eksisiting Desa Bodag maka dibutuhkan 3 jembatan pipa dengan menggunakan 3 perlintasan 3 Pipa GIP dengan diameter 4 inch. Tabel 3 dan Tabel 4 merupakan perhitungan panjang, jumlah pipa dan aksesorisnya berdasarkan dari kebutuhan pipa dengan program epanet.

Tabel 3. Kebutuhan pipa

\begin{tabular}{cccc}
\hline $\begin{array}{c}\text { Diameter } \\
\text { Pipa } \\
(\mathrm{mm})\end{array}$ & $\begin{array}{c}\text { Panjang } \\
\text { Pipa } \\
(\mathrm{m})\end{array}$ & $\begin{array}{c}\text { Diameter } \\
\text { Pipa } \\
\text { (inch) }\end{array}$ & $\begin{array}{c}\text { Jumlah } \\
\text { Pipa batang }\end{array}$ \\
\hline 100 & 3000 & 4 & 750 \\
75 & 100 & 3 & 25 \\
50 & 600 & 2 & 150 \\
38 & 350 & 1,52 & 88 \\
25 & 300 & 1 & 75 \\
\hline
\end{tabular}

Tabel 4. Kebutuhan aksesoris

\begin{tabular}{ccccc}
\hline D (mm) & $\begin{array}{c}\text { Panjang } \\
(\mathrm{m})\end{array}$ & $\begin{array}{c}\text { Satuan } \\
\text { Batang } \\
(\mathrm{m})\end{array}$ & $\begin{array}{c}\text { Jumlah } \\
\text { Pipa } \\
\text { (buah) }\end{array}$ & $\begin{array}{c}\text { Jumlah } \\
\text { Socket } \\
\text { (buah) }\end{array}$ \\
\hline 100 & 3200 & 4 & 800 & 800 \\
75 & 900 & 4 & 225 & 225 \\
50 & 600 & 4 & 150 & 150 \\
38 & 100 & 4 & 25 & 25 \\
30 & 250 & 4 & 62,5 & 63 \\
25 & 260 & 4 & 65 & 65 \\
\hline
\end{tabular}

Tabel 5 merupakan perhitungan BOQ (Bill of Quantity ) pekerjaan pemasangan pipa.

Tabel 5 perhitungan BOQ (Bill of Quantity ) pekerjaan pemasangan pipa per meter lari

\begin{tabular}{|c|c|c|c|c|c|c|c|c|c|c|c|c|c|c|c|}
\hline$\frac{\mathrm{D}}{(\mathrm{mm})}$ & $\mathrm{a}(\mathrm{m})$ & $\mathrm{b}(\mathrm{m})$ & $\mathrm{c}(\mathrm{m})$ & $\mathrm{d}(\mathrm{m})$ & 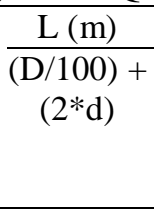 & 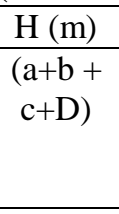 & $\begin{array}{l}\text { Panj. } \\
\text { Pipa } \\
(\mathrm{m})\end{array}$ & $\begin{array}{l}\text { Vol. gal } \\
\left(\mathrm{m}^{3}\right)\end{array}$ & $\begin{array}{l}\text { Vol. } \\
\text { Urug } \\
\text { tnh } \\
\text { kmbali }\end{array}$ & $\begin{array}{l}\text { Vol. } \\
\text { timbun } \\
\text { pasir } \\
\left(\mathrm{m}^{3}\right)\end{array}$ & $\begin{array}{c}\text { Vol. } \\
\text { tnh } \\
\text { dibuang } \\
\left(\mathrm{m}^{3^{\prime}}\right)\end{array}$ & $\begin{array}{l}\text { Total } \\
\text { Vol. } \\
\text { Gali } \\
\left(\mathrm{m}^{3}\right)\end{array}$ & $\begin{array}{l}\text { Total } \\
\text { Vol. } \\
\text { urug tnh } \\
\text { kembali } \\
\left(\mathrm{m}^{3}\right)\end{array}$ & $\begin{array}{c}\text { Total } \\
\text { Vol. } \\
\text { timbun } \\
\text { pasir } \\
\left(\mathrm{m}^{3}\right) \\
\end{array}$ & $\begin{array}{c}\text { Total } \\
\text { Vol. tnh } \\
\text { dibuang } \\
\left(\mathrm{m}^{3}\right)\end{array}$ \\
\hline 19 & 1,1 & 0,15 & 0,15 & 0,3 & 0,62 & 1,42 & 50 & 0,88 & 0,68 & 0,20 & 0,20 & 43,92 & 34,05 & 9,86 & 9,87 \\
\hline 25 & 1,1 & 0,15 & 0,15 & 0,3 & 0,63 & 1,43 & 250 & 0,89 & 0,69 & 0,20 & 0,20 & 22,66 & 171,88 & 50,66 & 50,78 \\
\hline
\end{tabular}


Tabel 5. (lanjutan) ...

\begin{tabular}{|c|c|c|c|c|c|c|c|c|c|c|c|c|c|c|c|}
\hline $\begin{array}{c}\mathrm{D} \\
(\mathrm{mm})\end{array}$ & $\mathrm{a}(\mathrm{m})$ & $\mathrm{b}(\mathrm{m})$ & $\mathrm{c}(\mathrm{m})$ & $\mathrm{d}(\mathrm{m})$ & 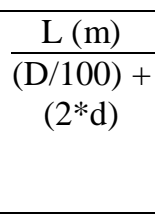 & $\begin{array}{c}\mathrm{H}(\mathrm{m}) \\
(\mathrm{a}+\mathrm{b}+ \\
\mathrm{c}+\mathrm{D})\end{array}$ & $\begin{array}{l}\text { Panj. } \\
\text { Pipa } \\
\text { (m) }\end{array}$ & $\begin{array}{c}\text { Vol.gal } \\
\left(\mathrm{m}^{3}\right)\end{array}$ & $\begin{array}{c}\text { Vol. } \\
\text { Urug } \\
\text { tnh } \\
\text { kmbali }\end{array}$ & $\begin{array}{c}\text { Vol. } \\
\text { timbun } \\
\text { pasir } \\
\left(\mathrm{m}^{3}\right)\end{array}$ & $\begin{array}{c}\text { Vol. } \\
\text { tnh } \\
\text { dibuan } \\
\left(\mathrm{m}^{3 \prime}\right)\end{array}$ & $\begin{array}{l}\text { Total } \\
\text { Vol. } \\
\text { Gali } \\
\left(\mathrm{m}^{3}\right)\end{array}$ & $\begin{array}{c}\text { Total } \\
\text { Vol. } \\
\text { urug tnh } \\
\text { kembali } \\
\left(\mathrm{m}^{3}\right)\end{array}$ & $\begin{array}{c}\text { Total } \\
\text { Vol. } \\
\text { timbun } \\
\text { pasir } \\
\left(\mathrm{m}^{3}\right)\end{array}$ & $\begin{array}{c}\text { Total } \\
\text { Vol. tnh } \\
\text { dibuang } \\
\left(\mathrm{m}^{3}\right)\end{array}$ \\
\hline 30 & & & & & & & & & & & & & 173,25 & 51,80 & \\
\hline 38 & & & & & & & & & & & & & & & \\
\hline 50 & & & & & & & 600 & & 0,7 & & & 565,50 & 429,00 & 135 & 136,50 \\
\hline 63 & & & & & & & 0 & & 0,73 & 0,24 & 0,2 & 0,00 & 0,00 & 0,00 & 0,00 \\
\hline 75 & & & & & & & 100 & & & & & 99,5 & 74,25 & 24, & 25,32 \\
\hline 90 & & & & & & & & & & & & 0,00 & 0,00 & 0 & 0,00 \\
\hline 110 & 1,1 & 0,15 & 0,15 & 0,3 & 0,71 & 1,51 & 3000 & 1,07 & 0,78 & 0,28 & 0,2 & 3216,30 & 2343,00 & 844,80 & 873,30 \\
\hline
\end{tabular}

Keterangan:

A = tinggi urugan tanah kembali

$\mathrm{b}=$ tinggi urugan pasir atas pipa kembali

$\mathrm{c}=$ tinggi urugan pasir bawah pipa

$\mathrm{d}=$ lebar urugan kanan kiri pipa

$\mathrm{L}=$ lebar galian

$\mathrm{H}=$ kedalaman galian total diubah-ubah sesuai kebutuhan

\section{KESIMPULAN}

1. Tingkat pendidikan masyarakat di Desa Bodag sebanyak $48 \%$ merupakan lulusan SD, sedangkan lulusan SMP dan SMA berturut-turut sebanyak $28 \%$ dan $20 \%$ serta $4 \%$ lulusan Perguruan Tinggi.

2. Jenis pekerjaan penduduk Desa Bodag adalah sebagian besar adalah petani dan peternak, yaitu sebanyak $89 \%$ dan $11 \%$.

3. Pendapatan bersih penduduk Desa Bodag adalah sebanyak Rp. 700.000,sebesar 66\%, lalu Rp. 500.000 sebesar 15\%, dan Rp. 1.200.000 sebesar 19\%.

4. Penduduk Desa Bodag yang sudah memiliki akses air bersih di rumah adalah $88 \%$, sedangkan sisanya $12 \%$ belum memiliki akses air bersih dirumah.

5. Penduduk yang sudah mendapat akses air bersih ternyata sebesar $8 \%$ responden yang jauh dari mata air dan sistem perpipaan, mengakses air bersih dengan menggunakan air sumur gali, air permukaan sungai dan air sumur dangkal. Sedangkan $92 \%$ mendapat air bersih dari mata air (perpipaan).

6. Saat diadakan penelitian masyarakat Desa Bodag sebanyak 1655 jiwa. Dengan proyeksi 10 tahun, diperkirakan jumlah penduduk meningkat sebanyak
20\%. Sehingga jumlah penduduk yang terlayani $=100 \% \times 1.2=1986$ jiwa.

7. Kebutuhan air bersih sebesar 3, 99 1/detik

8. Sumber air baku adalah mata air Sumber Nanas dengan besar debit air 8 1/detik.

9. Air dialirkan dahulu ke bangunan penangkap mata air/ PMA (broncaptering) yang berukuran $1 \mathrm{~m} \mathrm{x}$ $1 \mathrm{~m} \times 0,5 \mathrm{~m}$.

10. Perencanaan ini menggunakan pipa PVC dengan kriteria SNI S12,5 dengan arti kekuatan pipa tersebut adalah 10 bar.

11. Air bersih didistribusikan ke penduduk menggunakan SR halaman atau sambungan rumah yang hanya sampai halaman rumah sejumlah 397 rumah.

12. Diameter pipa beragam, pipa transmisi menggunakan diameter 4 inch sedangkan untuk pipa distribusi menggunakan pipa 3; 2; 1,5 dan 1 inch.

\section{SARAN}

Penelitian ini masih perlu pembenahan untuk luasan bangunan penangkap mata air dikarenakan saat musim hujan, debit air meningkat dan rembesan semakin banyak sehingga diperlukan perencanaan lanjutan yang survei lapangan dilaksanakan saat cutah hujan tinggi. Sehingga diperlukan juga 
perencanaan pengembangan untuk bak pelepas tekan atau menggunakan aksesoris airvalve diperbanyak sesuai dengan diameter pipa.

\section{UCAPAN TERIMA KASIH}

Ucapan terima kasih ditujukan kepada pemerintah dan masyarakat Desa Bodag serta teman-teman konsultan Program Penyediaan Air Minum dan Sanitasi Berbasis Masyarakat Kabupaten Madiun.

\section{REFERENSI}

[1] Panuluh, S., Fitri, M. R., 2016, Perkembangan Pelaksanaan Sustainable Development Goals (SDGs) di Indonesia. Biefing Pap, 02 infid, 1-25.

[2] Darajati, W., Sardjunani, N., 2017, Penyusunan rencana aksi.

[3] Bappenas Republik Indonesia Pembangunan Milenium Indonesia 2010. Bappenas.

[4] Farahdiba, A., Ulfah, Ramdhaniati, A., Soedjono, E. S., 2014, Pengembangan Teknologi Air Bersih Masyarakat dalam Rangkaian Percepatan MDG's 2015 Di Kabupaten Malang, J. Sains \&Teknologi Lingkung, 6, 48-62.

[5] Cameron, L., Shah, M., Sussan, O., 2013, Impact Evaluation of a Large-Scale Rural Sanitation Project in Indonesia: Policy Research Working Papers. Policy Res. Work. Pap.
[6] Mehta, V. N., Joshi, G. S., 2019, Design and analysis of rural water supply system using loop 4.0 and water gems V8i for Nava Shihora zone 1. Int. J. Eng. Adv. Technol. 9, 2258-2266.

[7] Pebakirang, A., Tanudjaja, L., Sumarauw, J. S. F., 2015, Perencanaan Sistem Penyediaan Air Bersih di Desa Munte Kecamatan Likupang Barat Kabupaten Minahasa Utara. J. Sipil Statik 3, 531-542.

[8] Pekerjaan Umum (Public Works), 2007, Penyelenggaraan pengembangan sistem penyediaan air minum.

[9] Widiyanto, W., 2010, Hitungan Diameter Pipa pada Sistem Penyediaan Air Minum sederhana Pipe Diameter Calculation on Simple Drinking Water System, Din. Rekayasa, 6, 26-32.

[10]Niazkar, M., Talebbeydokhti, N., Afzali, S. H., 2017, Relationship between HazenWilliam coefficient and Colebrook-White friction factor: Application in water network analysis, 513-520. 


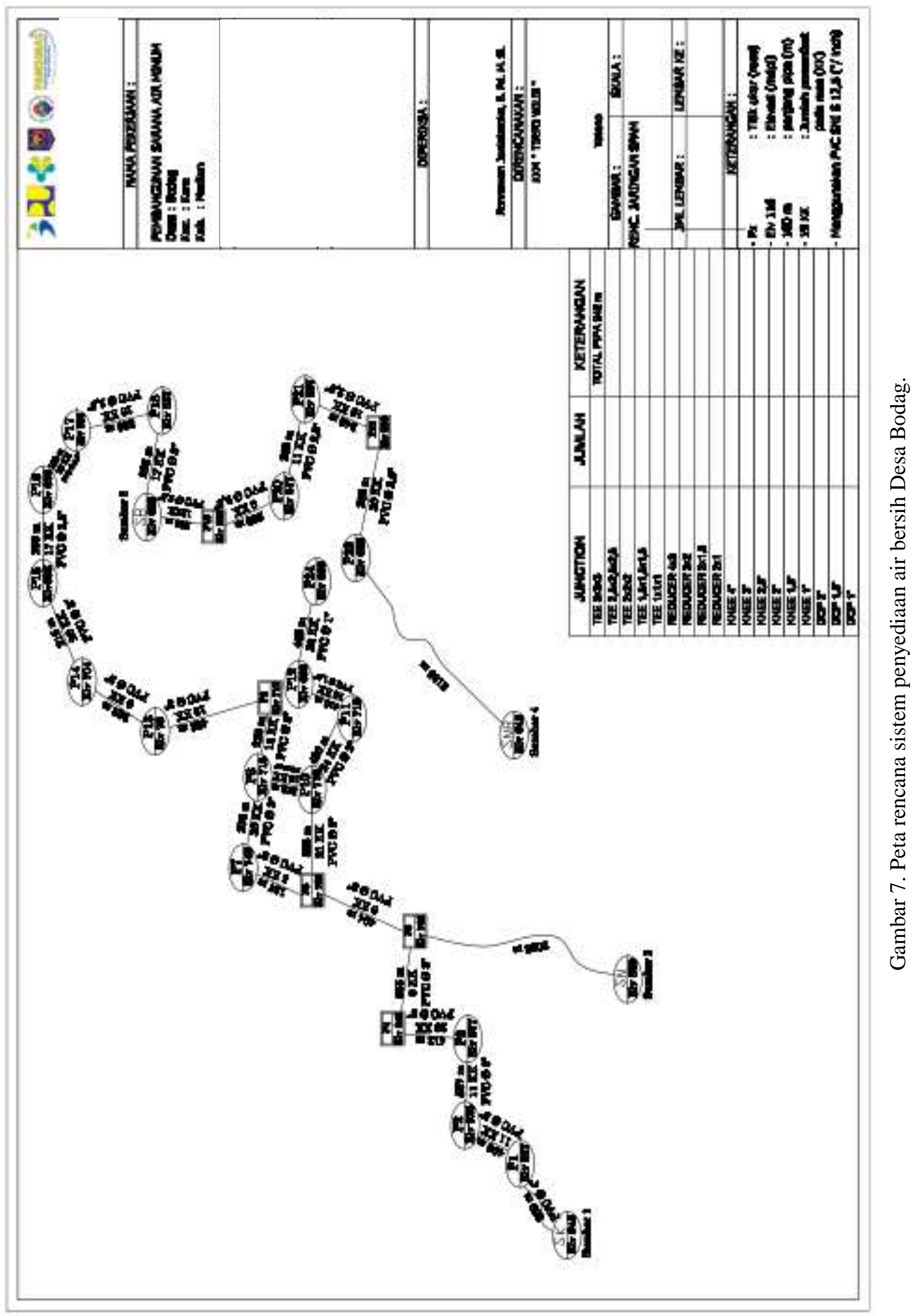

